\title{
Pengembangan Pariwisata Ekonomi Kreatif Desa Wisata Berbasis Budaya Sebagai Niche Market Destination (Studi Kasus Pengembangan Desa Wisata di Kabupaten Sleman)
}

\author{
Lastiani Warih Wulandari*
}

\begin{abstract}
This study purposed to describe tourism profile as a part of destination tourism.Cultural differences, together with asymmetry of the fruquent and transitory tourist -host contact, are the most important factor which influence interaction difficulties between tourist and host. Therefore, understanding of cross cultural tourist host contact and influenceof the cultural background of tourist and host is the key feature for identification of the cultural potential for tourist-host interaction and the effect of this interaction on the overall tourist holiday satisfaction
\end{abstract}

Key words : Tourist, host, interaction, satisfaction and competitive advantages.

\section{Pendahuluan}

Pariwisata di negara kita telah berkembang pesat dengan banyaknya obyek-obyek wisata yang banyak dikunjungi wisatawan baik dalam negeri maupun luar negeri. Salah satu yang masih perlu dikembangkan adalah Wisata yang berbasis Minat Khusus yang tentu saja hal baru yang masih perlu digali dimana industri tersebut marak pada era sekarang menjadi trend pasar dunia.

Pemasaran merupakan hal yang paling utama dalam ujung tombak pariwisata khususnya dimana hal yang terdepan ini menjadi parameter tingkat keberhasilan suatu produk. Wisata Minat Khusus ini menjadi salah satu hal menarik yang belum pernah. diangkat sebagai bagian 
terpenting nilai pelayanan jasa usaha pariwisata ; dalam hal ini pengembangan kegiatan berbasis budaya di desa wisata. Salah satu obyek pelayanan jasa usaha pariwisata yang sudah merambah ke Indonesia dan. khususnya ke wilayah Daerah Istimewa Yogyakarta

Pengembangan pariwisata berbasis budaya dengan mengendepankan wisata minat khusus ini banyak sekali berkembang di wilayah Indonesia, khususnya Daerah Istimewa Yogyakarta. Basis Budaya yang dimaksud disini adalah sebagai salah satu "ceruk pasar" potensial yang kita namakan Niche Market Destination. Pemanfaatan lahan di lingkungan Desa Wisata khususnya di Kabupaten Sleman masih perlu ditangani lebih jauh. Wisata Minat Khusus (Special Interest) merupakan daya tarik wisata yang dikembangkan lebih banyak berbasis pada aktivitas untuk pemenuhan keinginan wisatawan secara spesifik diantaranya seperti pengamatan satwa tertentu (bird watching), memancing (fishing), berbelanja (shopping), kesehatan dan penyegaran badan (spa and rejouvenation), arung jeram, wisata agro, MICE (meeting, incentive, conference and exebition) dan aktivitas-aktivitas minat khusus lainnya yang biasanya terkait dengan hobi atau kegemaran seseorang wisatawan

Desa Wisata yang sedang berkembang pesat sebagai harapan baik berkembangnya pariwisata di wilayah Kabupaten Sleman, khususnya menjadikan potensi pasar selain dari hotel-hotel yang marak berkembang selama ini. Harapan pengembangan wisata dengan minat khusus ini dapat dikemas sebagai bagian potensi pengembangan wisata dan dapat turut melestarikan budaya tradisonal warisan leluhur pusaka Nusantara dan akan menjadi salah satu pendorong pertumbuhan perekonomian di suatu daerah dengan mengkolaborasikan wisata dengan potensi yang telah 
dimiliki oleh masing-masing desa wisata dengan karakteristiknya menjadikan potensi pasar unik sebagai keunggulan bersaingnya.

Daerah Istimewa Yogyakarta sendiri sarat dengan budaya, sebagai kota budaya dan pendidikan dalam hal ini pariwisata berbasis budaya dengan dukungan keragaman obyek dan daya tarik wisata menjadi bagian terpenting sasaran pembangunan Yogyakarta sendiri, maka perlu strategi dalam memasarkan lebih spesifik dengan memiliki daya saing tinggi untuk menghasilkan nilai tambah (value added) pada terwujudnya kota Yogyakarta sebagai pariwisata berbasis budaya, khususnya Wisata Minat Khusus (Special Interst Tourism).

Salah satu jasa usaha pariwisata ini juga menjadi bagian terpenting untuk pengembangan potensi dan daya saing destinasi wisata dengan melakukan jejaring bermanfaat antar jasa usaha pariwisata untuk meningkatkan perekonomian masyarakat dengan menggali ceruk pasar yang unik sebagai strategi pengembangan daya saing destinasi wisata berupa Wisata Minat Khusus yang Berbasis Budaya.

Sebagai bagian destinasi yang harus dimunculkan daya saing dalam strategi pemasarannya,harus mampu menunjukkan keunggulan bersaingnya dalam desa wisata berbasis budaya ini . Salah satu contoh wisata minat khusus adalah industri di bidang kesehatan dan penyegaran badan (SPA dan Klinik Kesehatan) yang sarat dengan terapi menggunakan air yang juga dapat dilakukan di desa wisata, diterapkan sebagai niche market (ceruk pasar) dalam mengembangkan strategi pemasaran dan peningkatan daya saing destinasi wisata. Niche market merupakan pendekatan yang ditujukan untuk pasar spesifik dalam hal ini mengembangkan Wisata SPA berbasis budaya. Salah satu cara yang dapat dilakukan dalam pengembangan destinasi wisata ini dengan menggarap 
cerụk pasar khusus tersebut dan menerapkan metoda perawatan SPA tradisional dengan memanfaatkan alam dan mengangkat kearifan lokal. Pengembangan Desa Wisata berbasis budaya dapat saja menggunakan minat khusus berupa wisata SPA di Desa Wisata. Ini sudah dan sedang terus dikembangkan di Desa Wisata Kembang arum, Donokerto Turi Sleman Yogyakarta.

Menurut uraian diatas bahwa Wisata Minat Khusu Berbasis Budaya lainnya perlu dikembangkan yang merupakan kegiatan pejjalanan yang dilakukan wisatawan dengan tujuan mendapatkan jasa pelayanan usaha trmasuk memberi dampak positif terhadap budaya dan lingkungan. Contoh riel yang sudah dikembangkan adalah Wisata Minat Khusus SPA Berbasis Budaya yang sedang dilakukan di salah satu desa wisata Kembang Arum, Donokerto, Turi Sleman ini mengembangkan kearifan lokalnya dengan menggunakan bahan-bahan perawatan kesehatan berupa tanaman yang ada disekeliling desa wisata tersebut dan menggunakan juga tenaga trampil yang terstandar dari masyarakat komunitas setempat.

Ada 2 (dua) hal yang dapat meningkatkan pengembangan perekonomian kreatif dari dua sisi yang saling melengkapi dan keterkaitan ini sangat membawa dampak positif untuk masyarakat setempat dan industri terkait. Salah satu contoh dari Wisata SPA Desa Wisata yang kita sebut Wisata Minat Khusus yang berbasis budaya dan lingkungan , dimana sedang dilakukan di Desa Wisata Kembangarum, Turi tersebut berupa pelayanan wisata dengan mendapatkan perawatan kesehatan yang sudah tidak lagi dilakukan di tempat mewah atau mahal namun dari sisi produk (bahan lulur, dan perlengkapan lainnya), pengelolaan dan pelayanan wisata SPA yang dilakukan tetap terstandar dengan mengangkat nilai-nilai budaya dan melestarikan kearifan lokal 
dengan memanfaatkan sumber daya alam dari tanaman yang tumbuh di sekitar desa wisata tersebut sebagai Daerah Tujuan Wisata (DTW) SPA di Kembang Arum sebagai salah satu Desa Wisata di wilayah Kabupaten Sleman. Pemberdayaan masyarakat sekitar dengan pemanfaatan ketrampilan masyarakat pedesaan sekitar sebagai sumber daya manusia trampil dengan membuat bahan-bahan kosmetika tradisional, makanan minuman dari bahan-bahan yang berasal dari lingkungan desa wisata tersebut. Dengan demikian terjadi pemanfaatan lahan yang optimal dengan menjadikan bagian terpenting pasar yang unik atau memiliki keunikan berupa sebuah nilai (niche market value) .

\section{Landasan Teori}

Pengertian Pengembangan Destinasi Pariwisata (Tourism Product Design)

Dalam sub system produk kepariwisataan, beberapa komponen yang sangat penting untuk diperhatikan dalam pengembangan destinasi pariwisata. Beberapa hal terkait diantaranya Atraksi dan Daya Tarik Wisata (DTW), Amenitas atau Akomodasi, Aksesiblitas dan Transportasi, Infrastruktur Pendukung, Fasilitas Pendukung Pariwisata serta Kelembagaan dan Sumber Daya Manusia Pariwisata.

\section{Pengertian Daya Tarik Wisata Khusus Berbasis Budaya}

Istilah minat khusus ini lebih pada wisata dimana wisata yang dikembangkan merupakan sebuah aktivitas khusus yang menjadi bagian kegemaran/hobi dari wisatawan itu sendiri. Dari berbagai pengamatan yang mungkin di Tanah Air kita ini sangat kaya akan nilai tata cara kehidupan tradisional. Tatanan masyarakatnya dikemas sebagai sebuah 
atraksi dan daya tarik minat khusus dan merupakan salah satu atraksi yang sangat potensial untuk ditawarkan kepada wisatawan manca negara.

Produk wisata minat khusus yang dikemas secara khusus dengan berbasis budaya dan lingkungan ini menjadi pengembangan promosi wisata yang unik dengan mengemas menjadi sebuah events dan festival yang sangat menarik dan diselenggarakan secara periodik serta terjadwa! dalam suatu Calender of Events dan dipromosikan secara luas dan sistematis ( Sunarya, 2013).

Nilai kemasan events dari tata cara kehidupan tradisional yang disajikan sebagai daya tarik minat khusus ini yang sudah sangat tersohor baik dalam negeri maupun samapi ke manca negara seperti upacara ngaben di Bali, Batagak penghulu di Minangkabau, Khitanan di Parahyanngan, Sekaten di Solo dan Yogyakarta, upacara pingitan manten , prosesi pra nikah yang sudah ditinggalkan generasi muda sekarang.

Wisata berbasis budaya adalah salah satu kegiatan pariwisata yang menggunakan kebudayaan sebagai obyeknya dan pariwisata jenis ini dibedakan dari minat khusus. Pariwisata berbasis budaya di Indonesia telah ditunjukkan oleh beberapa provinsi, salah satunya provinsi Bali. Phillip F.McKean (1973) menulis bahwa "the tradition of Bali will prosper in direct propotion to the success of tourist industry"(dikutip dalam Wood, 1979).

Penerapan pariwisata berbasis budaya juga dimiliki oleh Daerah. Istimewa Yogyakarta yang sejak tahun 2008 mencanangkan diri sebagai kota pariwisata berbasis budaya. Makna dari Pariwisata Berbasis Budaya merupakan kegiatan pariwisata di Yogyakarta dikembangkan sesuai dengan potensi yang ada dan berpusat pada budaya Jawa yang selaras dengan sejarah dan budaya kraton Ngayogyakarta Hadiningrat sêtra 
menyempurnakan dan meningkatkan jaringan kerjasama wisata dengan pihak dan daerah lain.

Dalam pengembangan kepariwisataan sangat perlu mencermati perencanaan produk kepariwisataa (tourism product designing), sehingga produk wisata yang dihasilkan akan menjadi mudah untuk dipasarkan (marketable). Pendekatan keseimbangan antara permintaan (demand) dan penawaran (supply) dari suatu destinasi dan atau produk kepariwisataan dapat disesuaikan dengan variasi dan segmentasi kebutuhan dan ekspektasi (harapan) dari setiap ceruk pasar (niche market) wisatawan yang dibidik. (Sunaryo, 2013)

Wisata minat khusus ini seiring dengan perkembangannya menjadi salah satu daya tarik utama kunjungan wisatawan ke Indonesia sehingga pertumbuhan dan perkembangan industri di berbagai destinasi pariwisata menempatkan Indonesia sebagai salah satu destinasi yang menarik dan kompetitif dan potensi ini juga akan menciptakan lapangan kerja yang besar di industri pariwisata.

\section{Keterkaitan (Linkage) dalam Perencanaan Pengembangan Wisata (Destinasi Wisata)}

Destinasi wisata yang telah berkembang baik pada hakekatnya dilihat dari fenomena kunjungan wisatawan ke suatu destinasi baik dari kunjungan wisatawan domestik maupun luar negeri (internasional) yang memberikan implikas tumbuhnya kegiatan-kegiatan usaha terkait. Sinergi antara keterkaitan usaha dan kegiatan berimplikasi sebagai untaian rantai kegiatan yang saling terkait baik secara rantai nilai ke depan (forward linkage) maupun sisi lain rantai nilai keterkaitan ke belakang (backward linkage). Sistem Kepariwisataan tersebut akan membentuk kesatuan 
sistem interaksi diantara komponen baik usaha dan kegiatannya atau aktivitas kepariwisataan yang tidak bisa terpisahkan satu dengan yang lain menjadi suatu kegiatan yang bersifat holistic (menyeluruh).

Daya tarik wisata minat khusus (special interest) merupakan daya tarik wisata yang dikembangkan dengan lebih banyak berbasis pada aktivitas untuk pemenuhan keinginan wisatawan secara spesifik terkait dengan hobi atau kesukaan/kegemaran seorang wisatawan. Dalam mempromosikan dan menjual produk wisata minat khusus ini yaitu Desa Wisata Berbasis Budaya yang memiliki keunikan tersendiri (ciri khas) dengan dikemas sedemikian rupa dengan tata cara kehidupan tradisional masyarakat Indonesia merupakan salah satu atraksi dan daya tarik minat khusus yang sangat potensial untuk ditawarkan kepada wisatawan.

Seluruh lingkungan fisik, sosial budaya beserta potensi sumber daya wisata alam, budaya dan sumber daya wisata khusus yang ada dan dapat dikelola serta dikembangkan untuk menjadi daya tarik kunjungan bagi wisatawan. Menurut beberapa ahli seperti Mariotti (1985) dan Yoeti (1987) mengemukakan bahwa daya tarik destinasi merupakan faktor yang paling penting dalam menarik wisatawan untuk berkunjung dan memenuhi 3 (tiga) syarat yaitu Something to See yaitu destinasi tersebut harus mempunyai daya tarik khusus yang dapat dilihat oleh wisatawan, disamping juga harus mempunyai atraksi wisata yang dapat dijadikan entertainments bila orang datang mengunjunginya. Syarat kedua adalah Something to Do yaitu menyediakan beberapa fasilitas rekreasi atau amunesements dan tempat atau wahana yang bisa digunakan oleh wisatawan untuk beraktivitas sehingga membuat wisatawan betah tinggal lebih lama. Yang ketiga adalah Something to Buy dimana harus tersedia 
barang-barang cindera mata yang dihasilkan dari kerajinan masyarakat setempat yang dapat dibeli untuk dibawa pulang ke asal wisatawan.

Desa Wisata yang berbasis budaya yang memiliki komponen keterkaitan ke belakang (backward linkage) berupa produk dengan mengedepankan budaya dan linkungan yang dimiliki oleh desa wisata masing-masing. Salah satu contoh Desa Wisata Kembangarum Turi tersebut dengan ciri khan tanaman salak sangat berpotensi untuk memiliki nilai keunggulan bersaing dari lingkungannya yang dapat dikembangkan sebagai bahan-bahan makanan tradisional dan bahan-bahan kosmetika tradisonal . Lingkungan sekitar masyarakat semakin berdaya dengan mengolah bahan makanan dan minuma berbahan dasar salak. Faktor keterkaitan ke depan (forward linkage) lebih pada pembangunan sumber daya alam, lingkungan dan manusia berupa masyarakat yang memiliki berbagai ketrampilan yang terkait dengan wisata minat khusus yang selaras dengan lingkungan alam di Desa Wisata tersebut.

\section{Strategi Market Nicher Desa Wisata Berbasis Budaya}

Desa Wisata sebagai bagian dari usaha jasa pelayanan pariwisata yang merupakan bentuk minat khusus yang tengah di kembangkan oleh Kementrian Pariwisata dan Ekonomi Kreatif. Dalam menjaring wisatawan mancanegara, wisata dalam Desa Wisata sebagai minat khusus berbasis budaya ini merupakan salah satu potensi pariwisata unggulan yang dimiliki Indonesia bahkan Kabupaten Sleman Yogyakarta. Potensi ini akan menjadi komoditi andalan,dengan kondisi strategis dan merupakan pasar yang unik, Desa Wisata Berbasis Budaya ini tidak perlu mengejar kuantitas atau jumlah wisatawan namun lebih pada mengejar kualitas dimana pengeluaran wisatawan saat berkunjung cukup tinggi dan lama 
tinggal yang panjang. "Lenght of Stay atau lama tinggal wisatawan diukur dari lamanya wisatawan menginap di suatu destinasi" (Akhyarudin, 2014). Relung pasar/pasar ceruk (niche market) inilah yang dapat menjadi kekuatan pariwisata Indonesia

Perubahan gaya hidup di dunia menggeser pola hidup seseorang yang menjadikan permintaan atas penawaran dengan tempat-tempat untuk santai/rileks, menghilangkan stress, melepas kepenatan, kelelahan dari segala kesibukan dan rutinitas aktifitas sehari-hari juga memberikan kesempatan untuk mencari tempat wisata yang sesuai dengan kegemaran atau kesenangan masing-masing wisatawan.. Metode kemasan layanan di Desa Wisata yang ditawarkan bermacam-macam mulai dari cara tradisional sampai modern dengan suasana yang alami, unik, bernuansa magis hingga arsitek bangunan yang menunjukkan keunikan sampai dengan penggunaan bahan-bahan pilihan yang memikat menjadi menu unik mulai dari layanan inap, makanan dan minuman yang disuguhkan sampai wisatawan ikut terlibat dalam situasi dan kegiatan yang ditawarkan oleh Desa Wisata tersebut.

Kembangarum sebagai andalan Desa Wisata yang telah ménerapkan Wisata Berbasis Budaya dengan memiliki fasilitas dan infrastrukrtur yang mendukung aktivitas wisata diantaranya -dengan kegiatan tracking seperti mengelilingi desa dengan tipikal keramahan suasana pedesaaan dan susur sungai, sajian permainan untuk wisatawan yang tidak hanya menginap namun terlibat dalam sebuah pengalaman yang ditawarkan dengan permainan tradisional seperti bermain dingklik estafet, balap bakiak, egrang, memet ikan dan SPA (massage) dengan menggunakan bahan-bahan ramuan tradisional yang diramu komunitas penduduk sekitar Desa Wisata tersebut. Mengutip dari hasil survey 
internasional yang bertajuk "Global Tourism Intentions Survey" mengemukakan bahwa sebuah pembiayaan kartu ternama membuktikan kalangan wisatawan mancanegara biasanya merencanakan perjalanan wisata tanpa jasa agen perjalanan mereka menghabiskan sekitar $\mathrm{Rp} 13.5$ juta per orang bahkan bersedia merogoh uang lebih demi menikmati kenyamanan wisata tradisional (contohnya Desa Wisata) di Indonesia. Survey dilakukan terhadap 11.620 responden dari 23 negara di dunia dan mengungkapkan pelayanan wisata tersebut mampu menyedot minat 3.2 persen wisatawan asing untuk datang ke suatu negara, termasuk Indonesia yang memiliki karakteristk tatanan kehidupan masyarakat yang unik yang tidak dapat ditemukan di tempat lain.

\section{Pariwisata Ekonomi Kreatif}

Dewasa ini pariwisata telah menjadi salah satu industri andalan utama sebagai primadona karena beberapa ciri positifnya dimana Indonesia salah satunya memiliki potensi pariwisata baik dari segi alam maupun dari sisi sosial budaya. Destinasi pariwisata merupakan area atau kawasan geografis yang berada dalam satu atau lebih wilayah administratif yang didalam nya terdapat unsur-unsur yang saling terkait dan melengkapi untuk terwujudnya kegiatan kepariwisataan dengan dukungan manajemen dan regulasi.

Daerah tujuan wisata yang disebut Destinasi Pariwisata menurut UU Kepariwisataan no 10 tahun 2009 (pasal1) menyatakan bahwa kawasan geografis yang berada dalam satu atau lebih wilayah administratif yang didalamnya terdapat daya tarik wisata, fasilitas umum, fasiltas pariwisata, aksesibilitas serta masyarakat yang saling terkait dan melengkapi terwujudnya kepariwisataan. 
Tujuan pengembangan destinasi pariwisata di tahun ini adalah míngembangkan destinasi pariwisata yang berdaya saing serta däpat memberikan kontribusi yang signifikan terhadap perekonomian nasional dan kesejahteraan masyarakat. Sasaran yang dicapai adalah meningkatkan lama tinggal dan pengeluaran wisatawan dengan terwujudnya destinasi berdaya saing internasional untuk terwujudnya kapasitas pengelolaas destinasi pariwisata serta terwujudnya diversifikasi destinasi pariwisata.

Strategi destinasi pariwisata lebih pada pendekatan dari tarikan pasar (market attractiveness), dorongan produk (pushing product), peran serta kelembagaan dan manajemen (institution and management), peningkatan investasi (investment encouragement) dan pemberdayaan masyarakat (community empowerement).

Pemahaman wisatawan juga sangat bervariasi, batasan secara umum hingga sangat teknis spesifik diantaranya disampaikan oleh United Nation Conference on Travel and Tourism di Roma (1963) bahwa batasan lebih umum wisatawan dengan istilah visitor (pengunjung) adalah "Setiap orang yang mengunjungi negara yang bukan merupakan tempat tinggalnya, untuk berbagai tujuan tetapi bukan untuk mencari pekerjaan atau penghidupan dari negara yang dikunjunginya". Batasan lain dikemukakan oleh Leiper (1995:11) bahwa:

" Tourist can be defined in behavioural terms as persons who travels away from their normal residential region for temporary period of at least one night, to the extent that their behaviour involves as search for leisure experiences fom interactions with features or characteristics of placesthey choose to visit" 
$\because$..ji Tipologi wisatawan dalam mengunjungi daerah tujuan wisata, menurt Gray(1970) membedakan wisatawan menjadi dua. Pertama disebut dengan Sunlust Tourist adalah wisatawan yang berkunjung ke suatu daerah dengan tujuan utama untuk beristirahat atau relaksasi sehingga mengunjungi daerah tujuan wisata dengan ciri multiple $S$ (sun,sea,sand) dengan mrngharapkan keadaan iklim, fasilitas, makanan dan lainnya sesuai dengan standar di negara asainya. Kedua adalah Wanderlust Tourist yaitu wisatawan yang perjalanan wisatanya didorong oleh motivasi untuk mendapatkan pengalaman baru, mengetahui kebudayaan barunya dan mengagumi keindahan alam yang belum pernah dilihatnya, wisatawan yang tergolong dalam tipikal kedua ini lebih tertarik pada daerah tujuan wisata yang mampu menawarkan keunikan budaya atau pemandangan alam yang mempuriyai nilai pembelajaran yang tinggi.

Pada dasarnya seseorang melakukan perjalan wisata seringkali dimotivasi oleh beberapa hal, menurut McIntosh(1977) dan Murphy (1985, ef Sharpley, 1994) mengemukakan bahwa motivasi wisatawan dalam melakukan perjalanan ke daerah tujuan wisata dikelompokkan sebagai berikut :

a. Physical or physiological motivation (motivasi yang bersifat fisik atau fisiologis) berupa relaksasi, kesehatam, kenyamanan, berpartisipasi dalam kegiatan olah raga, bersantai dan sebagainya.

b. Cultural motivation (motivasi budaya) merupakan keinginan untuk mengetahui budaya, adat, tradisi dan kesenian daerah lain juga termasuk ketertarikan akan berbagai obyek tinggalan budaya. 
c. Social motivation atau interpersonal motivation (motivasi yang bersifat social) seperti mengunjungi teman/keluarga, mitra kerja, ziarah, pelarian dari hal-hal yang membosankan dan lainnya.

d. Fantasy motivation (motivasi karena fantasy) dengan melakukan fantasi ke daerah lain seseorang akan bisa lepas dari rutinitas keseharian yang menjemukan dan ego-enhancement yang memberikan kepuasan psikologis (status and prestige motivation). Krippendorf (1997:39-42 dalam Pitana) juga mengemukakan bahwa motivasi seorang wisatawan melakukan perjalanan sangat bervariasi dan motivasi tersebuttidak selalu tunggal melainkan kombinasi dari berbagai motivasi. Studi yang telah dilakukan pada tahun 1986 menyatakan bahwa presentase wisatawan dengan motivasi-motivasi utama di dalam melakukan perjalan wisata adalah rekuperasi dan regenerasi, kompensasi dan integrasi sosial, escape, komunikasi, memperluas pengalaman, kebebasan dan determinasi diri, realisasi diri dan untuk bersenang-senang. Secara detail berbagai motivasi dapat dilihat pada Tabel dibawah ini.

Tabel 1. Motivasi Perjalanan Daerah Tujuan Wisata (DTW)

\begin{tabular}{|c|l|l|}
\hline $\begin{array}{l}\text { Travel is recuperation and } \\
\text { regeneration }\end{array}$ & $\begin{array}{l}\text { Perjalanan wisata merupakan penyegaran dan } \\
\text { regenerasi fisik dan mental }\end{array}$ \\
\hline $\begin{array}{l}\text { Travel is compensation and } \\
\text { social integration }\end{array}$ & $\begin{array}{l}\text { Perjalanan wisata merupakan } \\
\text { terhadap berbagai hal yang melelahkan sekaligus } \\
\text { juga berfungsi sebagai wahana integrasi sosial } \\
\text { bagi mereka yang rumahnya merasa teralienasi }\end{array}$ \\
\hline Travel is escape & $\begin{array}{l}\text { Perjalanan wisata merupakan "pelarian" dari } \\
\text { situasi keseharian yang penuh } \\
\text { ritinitas yang menjemukan atau } \\
\text { kejenuhan karena beban kerja }\end{array}$ & kejenuhan, \\
\hline Travel is communication & $\begin{array}{l}\text { Perjalanan wisata merupakan mekanisme bagi } \\
\text { seseorang untuk dapat mengeluarkan } \\
\text { perasaannya melalu komunikasi dengan orang } \\
\text { lain termasuk dengan masyarakat lokal. }\end{array}$ \\
\hline
\end{tabular}




\begin{tabular}{|c|l|}
\hline Travels broadens the mind & $\begin{array}{l}\text { Perjalanan wisata merupakan wahana untuk } \\
\text { mengembangkan wawasan }\end{array}$ \\
\hline $\begin{array}{c}\text { Travel is freedom and self } \\
\text { determination }\end{array}$ & $\begin{array}{l}\text { Perjalanan wisata merupakan wahana untuk } \\
\text { mendapatkan kebebasan dengan berbagai secular } \\
\text { ritual atau dengan berbagai inversi yang dapat } \\
\text { dilakukan }\end{array}$ \\
\hline Travel is self realization & $\begin{array}{l}\text { Perjalanan wisata merupakan wahana untuk } \\
\text { realisasi diri }\end{array}$ \\
\hline Travel is happiness & $\begin{array}{l}\text { Perjalanan wisata merupakan sesuatu yang } \\
\text { menyenangkan dan membuat hidup lebih } \\
\text { bahagia. }\end{array}$ \\
\hline
\end{tabular}

Keputusan seseorang untuk melakukan perjalanan wisata dipengaruhioleh kuatnya faktor-faktor pendorong (push factor) dan faktor penarik (pull factor). Faktor pendorong dan penarik ini merupakan faktor internal dan eksternal yang memotivasi wisatawan untuk mengambil keputusan dalam melakukan perjalan wisata, dimana faktor pendorong umumnya bersifat sosio psikologis sedangkan faktor penarik merupakan destination spesific attributes.

Adanya faktor pendorong mengakibatkan seseorang ingin melakukan perjalanan wisata dan adanya berbagai faktor penarik yang dimiliki oleh daerah tujuan wisata (DTW) menyebabkan seseorang akan memenuhi kebutuhan dan keinginan (needs and wants) untuk memilih daerah tujuan wisata yang dikehendaki. Beberapa faktor pendorong seseorang untuk melakukan perjalanan wisata menurut Ryan (1991 dalam Pitana, 2005) antara lain sebagai berikut :

a. Escape. Ingin melepaskan diri dari lingkungan yang dirasakan menjemukan atau kejenuhan sehari-hari.

b. Relaxation. Keinginan untuk rekuperasi/penyegaran yang juga berhubungan dengan motivasi untuk escape. 
c. Play. Ingin menikmati kegembiraan, melalui berbagai permainan yang merupakan pemunculan kembali dari sifat kekanak-kanakan dan melepaskan diri sejenak dari berbagai urusan serius.

d. Strenghthening Family Bonds. Ingin mempererat hubungan kekerabatan. Keakraban hubungan kekerabatan ini juga terjadi diantara anggota keluarga (visiting friends and relations) yang melakukan perjalanan bersama-sama dan karena kebersamaan sangat sulit diperoleh dalam suasana kerja sehari-hari di negara industri.

e. Prestige. Untuk menunjukkan gengsi, dengan mengunjungi destinasi yangmenunjukkan kelas dan gaya hidup yang juga merupakan dorongan untuk meningkatkan status atau derajad sosial.

f. Social Interaction. Untuk melakukan interaksi sosial dengan teman sejawat atau dengan masyarakat lokal yang dikunjungi.

g. Romance. Keinginan untuk bertemu dengan orang-orang yang bisa memberikan suasana romantic.

h. Educational Opportunity. Keinginan untuk melihat sesuatu yang baru mempelajari orang lain/daerah lain atau mengetahui kebudayaa etnis lain dan ini merupakan pendorong dominan di dalam pariwisata

i. Self Fullfilment. Keinginan untuk menemukan diri sendiri, karena diri sendiri biasanya bisa ditemukan pada saat kita menemukan daerah atau orang yang baru.

j. Wish Fullfilment. Keinginan untuk merealisasikan mimpi-mimpi yang lama dicita-citakan sampai mengorbankan diri dengan cara berhemat agar bisa melakukan perjalanan. 
Dalam perkembangan lebih jauh muncul tujuan dan motivasi yang lebih spesifik dan kemudian membuka pintu untuk berkembangnya pariwisata minat khusus (special interest tourism) yang sering disebut sebagai new tourism (Richardson and Fluker, 2004 dalam Pitana) . Dibawah ini tabel tentang contoh special interest tours.

Tabel 2 Beberapa Contoh Special Interest Tours

\begin{tabular}{|c|l|}
\hline Kelompok Minat Khusus & \multicolumn{1}{|c|}{ Aktivitas } \\
\hline Active Adventure & $\begin{array}{l}\text { Caving, parachute jumping, trekking, off road } \\
\text { adventure, mountan climbing }\end{array}$ \\
\hline Nature and ildlife & $\begin{array}{l}\text { Birdwatching,ecotourism,geology,national park, } \\
\text { rainforest }\end{array}$ \\
\hline History/culture & $\begin{array}{l}\text { Agriculture,art/architecture, art festivals,film/film } \\
\text { history, winery tours }\end{array}$ \\
\hline Spritual & $\begin{array}{l}\text { Blibicaltours,churchtours,pilgrimage/mythology, } \\
\text { religion/spiritual, yoga and spiritual tours }\end{array}$ \\
\hline Sport & Basket ball,car racing,olympic games,soccer \\
\hline Hobby & $\begin{array}{l}\text { Antiques, brewer/beerfstivals, craft tours, } \\
\text { gambling, videography tours }\end{array}$ \\
\hline Romance & $\begin{array}{l}\text { Honeymoon, Island vacation,nightlife,single } \\
\text { tours, SPA/Hot Spring }\end{array}$ \\
\hline Affinity & $\begin{array}{l}\text { Artists workshop,gay tours, lesbian tours, senior } \\
\text { tours, tours for handicapped }\end{array}$ \\
\hline Soft Adventure & $\begin{array}{l}\text { Backpacking,bicycle } \\
\text { touring,canoing/kayaking,scuba,diving } \\
\text { snorkling, walking tours }\end{array}$ \\
\hline Family & $\begin{array}{l}\text { Amunesement park,camping,shopping } \\
\text { trips,whalewatching, gourmet/gastronomy }\end{array}$ \\
\hline
\end{tabular}

Richardson and Flukers, 2004:71 dalam Pitana, 2005

Perlu disadari bahwa Indonesia sudah masuk dalam era liberalisasi perekonomian global sehingga konsekuensi logis dari hal tersebut berbagai destinasi di Indonesia ini harus mempersiapkan diri dan mengikuti "rule of the game" untuk mencapai target kunjungan wisatawan. Indonesia menempati peringkat 6 (enam) dibanding negara lain yaitu Singapura, Thailand, Malaysia,Filipina, Vietnam dan Australia 
sébagai negara yang memiliki daya saing kepariwisataannya. Potret Indonesia dapat menjadi bahan refleksi pemangku kepentingan industri pariwisata khususnya Daerah Istimewa Yogyakarta untuk mengantisipasi dengan merumuskan daya saing lebih pada menekankan faktor-faktor generik yang justru dapat membentuk daya saing sebuah destinasi wisata.

Faktor-faktor yang mempengaruhi daya saing dan menemukan model pariwisata khususnya Wisata Minat Khusus di Desa Wisata yang sesuai dengan keinginan dan kebutuhan masyarakat sehingga akan meningkatkan image/citra industry Desa Wisata di mata masyarakat yang akan menentukan daya saing dengan hotel-hotel yang marak berkemband dengan mengedepankan Desa Wisata Berbasis Budaya.

Pengertian daya saing dapat diterjemahkan dari sisi permintaan (demand side) dan sisi penawaran (supply side). Demand side yang dimaksud kemapuan bersaing mengandung arti bahwa produk pariwisata yang dijual haruslah produk yang sesuai dengan atribut konsumen atau produk yang dipersepsikan bernilai tinggi (consumer's value perception). Perubahan atas nilai pada konsumen sangat mempengaruhi perilaku dalam membeli suatu produk pariwisata.

Perubahan nilai tersebut dimaksud yang pertama adalah semakin meningkatnya kesadaran konsumen akan pentingnya kaitan kesehatan, kecantikan dan kebugaran dan pola gaya hidup tentang makanan sehingga meningkatnya tuntutan konsuen akan makanan yang mengandung nutrisi, produk-produk menyehatkan (healthy), aman (safety) dan menunjang kebugaran (fitness). Nilai kedua adalah perubahan gaya hidup (life style) masyarakat telah merubah pola dan gaya konsumsi akan produk-produk pariwisata yang bukan sekedar berdimensi fisiologis namun lebih luas pada dimensi psikologis dan kenikmatan (amenities). Yang ketiga adalah 
meningkatnya kesadaran masyarakat internasional yang berkaitan dengan kelestarian lingkungan hidup yang mendorong masuknya aspek kelestarian lingkungan dalam pengambilan keputusan ekonomi.

Supply side atau dari sisi penawaran merupakan kemampuan bersaing yang berkaitan dengan kemampuan merespons perubahan atribut-atribut produk yang dituntut oleh konsumen secara efisien. Kemampuan dalam merespon sisi penawaran ini menyangkut yang pertama adalah integrasi vertikal mulai dari hulu sampai ke hilir dari suatu sistem pariwisata komoditas pada suatu produk (product line). Atribut produk akhir pariwisata merupakan hasil kumulatif dari semua sub sistem pariwisata dari hulu sampai ke hilir sehingga pengelolaan secara integrasi vertikal suatu sistem pariwisata yang menjamin transmisi informasi pasar secara sempurna dan cepat dari hilir ke hulu dengan meminimkan margin ganda dan menjaga konsistensi mutu produk dari hulu ke hilir sehingga dapat menentukan ketepatan dan kecepatan merespon perubahan pasar. Hal pokok yang kedua adalah sumber kekuatan sistem dan usaha pariwisata dalam merespon pasar dalam merespon atribut-atribut produk yag dituntut konsumen dimana sistem pariwisata tidak dapat mengandalkan kekuatan alam dan sumber manusia tidak terdidik (factor driven). Perubahan-perubahan pasar hanya dapat direspon dengan kekuatan modal dan sumber daya manusia yang lebih terdidik (capital driven) dan mengandalkan ilmu pengetahuan teknologi dan sumber daya manusia terampil (innovation driven)

Faktor-faktor penentu diatas yang akan menjadi faktor keterkaitan dimana faktor forward linkage (keterkaitan kedepan) dan backward linkage (keterkaitan ke belakang) akan memberikan nilai dari hulu ke hilir 
dálam merespon atribut-atribut produk sebagai sistem komoditas, khususnya untuk industri Desa Wisata ini.

Sisi penawaran tidak lagi hanya melihat factor driven dari sumber daya manusianya (masyarakat/penduduk sekitar yang terkena imbas positif dalam membuka lapangan pekerjaan) namun perubahan pasar yang menghendaki capital driven dan innovation driven bersama-sama membentuk nilai tambah (value added) sehingga pemenuhan integrasi vertikal product line dari hulu ke hilir dapat memenuhi sisi permintaan (supply side) yang sudah lebih mengarahkan Wisata Minat Khusus ini dalam sebuah Desa Wisata yang terakomodir dengan lebih optimal baik dari sisi produk (makanan, minuman dan perlengkapan lainnya yang disajikan dari lingkungan dan budaya setempat, pengelolaan dan pelayanan wisata yang berbasis budaya setempat).

Sumber daya manusia yang terdidik, dan sumber daya alam serta sumber daya penyerta lainnya (lingkungan) yang berbasis budaya dengan melibatkan pemberdayaan masyarakat juga sesuai dengañ keinginan dan kebutuhan konsumen sebagai sebuah atribut untuk menentukan pengembangan standar pelayanan jasa usaha pariwisata yang memiliki nilai keunggulan bersaing

\section{Metode Penelitian}

Penelitian ini untuk mendapatkan gambaran tentang Desa Wisata berbasis budaya sebagai ceruk pasar yang memiliki keunggulan bersaing dengan batasan ruang lingkup sebagai berikut :

a. Ruang Lingkup Makro yaitu ruang lingkup Desa Wisata di wilayah Daerah Istimewa Yogyakarta dengan lingkup pengembangan standar pelayanan Desa Wisata . 
b. Ruang Lingkup Mikro yaitu ruang lingkup penelitian dalam hal ini pengembangan untuk standar pelayanan Desa Wisara yang berbasis budaya yang ada di desa wisata Kembangarum Donokerto, Turi, Sleman, Yogyakarta.

Desa wisata Kembangarum yang letaknya di lereng gunung merapi sekitar $19 \mathrm{~km}$ dari pusat kota dengan jarak tempuh sekitar 30 menit, memiliki luas tanah sekitar 22 hektar dengan jumlah penduduk sekitar 269 orang dan sudah memiliki berbagai macam produk wisata diantaranya out bound, SPA, home stay, kuliner, pendidikan dan atraksi lainnya yang ditujukan untuk wisata alam. Dalam hal ini Kembangarum menjadi saläh satu tempat yang sarat dengan wisata alam sebagai salah satu sumber daya yang dapat dikembangkan dalam Desa Wisata Berbasis Budaya dengan melibatkan sumber daya yang ada sebelumnya baik sumber daya alam dan sumber daya manusia yang nantinya dapat memberikan potensi keunggulan bersaing.

Pengembangan pelayanan sebagai destinasi Desa Wisata perlu standar dengan mengangkat kearifan lokal berbasis budaya dan kemasyarakatan yang mana akan memberikan nilai tambah (value added) Desa Wisata pada umumnya dan kontribusi positif dalam meningkatkan kembali image/citra (re-image) positif standar pelayanan industri tersebut dengan pemberdayaan masyarakat melalu pariwisata, khususnya di wilayah Kabupaten Sleman. Berdasarkan hal diatas maka perlu dipilih lokasi penelitian dengan pertimbangan sebagai berikut:

a. Destination Desa Wisata merupakan sebuah desa di alam terbuka yang melibatkan pelayanan wisata dengan pendekatan aspek pelayanan yang terstandar sehingga akan menjadi bagian terpenting 
b. Desa Wisata Berbasis Budaya dalam hal ini melibatkan aspek produk 'dan pengelolaan sumber daya alam dan sumber daya manusia dengan melibatkan langsung potensi kearifan lokal dan pemberdayaan masyarakat.

c. Pengembangan ekonomi kreatif menjadikan keunggulan bersaing dan citra positif Desa Wisata dalam upaya peningkatan kepuasan pelanggan.

d. Desa Wisata yang berbasis budaya ini merupakan pasar relung (niche 'market/ceruk pasar) dalam segmentasi pasar sebagai spesialisasi untuk pemenuhan kebutuhan dan keinginan pasar tertentu, dalam hal ini wisatawan yang tinggal di hotel-hotel akan bergeser dengan mendapatkan pelayanan yang memenuhi kebutuhan dan keinginan wisatawan tersebut dengan mengangkat kearifan lokal dan pemanfaatan wisata berbasis budaya dan lingkungan.Dengan demikian konsumen akan mendapatkan sesuatu yang lebih (value) atau mendapatkan nilai-nilai tertentu, dalam hal ini sebuah nilai budaya khas tradisional.

\section{Jenis Data dan Cara Pengumpulannya}

Dalam hal ini menggunakan jenis data dan cara pengumpulannya sebagai berikut :

1. Data Primer dan Proses Pengumpulannya

a. Wawancara terstruktur menggunakan kuisioner yang merupakan teknik pengumpulan data yang dilakukan dengan cara mengajukan 
pertanyaan dalam kuisioner. Wawancara dilakukan pada sampel yang sudah ditentukan sesuai dengan tujuan penelitian tersebut.

b. Wawancara mendalam lebih menggunakan pedoman wawancara . yang dilakukan kepada sumber yang bisa memberikan informasi secara lebih mendalam berkaitan dengan permasalahan penelitian.

c. Observasi merupakan pengamatan baik secara langsung maupun tidak langsung dan melakukan pencatatan secara sistematis tentang fenomena obyek yang diteliti

2. Data Sekunder dan Proses Pengumpulannya

Pengambilan data sekunder diperoleh dari berbagai sumber antara lain:

a. Dinas Kebudayaan dan Pariwisata Kabupaten Sleman

b. Forum Komunikasi Desa Wisata

c. Standar Pelayanan Jasa Usaha Desa Wisata yang dikeluarkan oleh Kemenparekraf.

d. Data Pustaka terkait lainnya yang diperoleh di instansi terkait.

\section{Data dan Pembahasan}

\section{Karakteristik Responden}

Responden dalam penelitian ini adalah desa wisata yang ada di kabupaten Sleman sebanyak 39 desa wisata dengan karakteristik yang berbeda-beda. Diambil data desa wisata baik dari wisata domestik/nusantara dan wisata manca negara yang memiliki karakteristik yang hampir sama ada 8 (delapan) desa wisata antara lain; Desa wisata Brayut, Sleman, Tanjung Ngaglik, Sambi Pakem, Grogol Sayegan, Srowolan Banyusumilir, Kembangarum Turi, Kelor Turi dan Pentingsari Cangkringan. 


\begin{tabular}{|c|c|c|c|c|c|c|c|c|c|c|c|c|c|c|}
\hline No & $\begin{array}{l}\text { Obyek } \\
\text { Wisata }\end{array}$ & $\begin{array}{c}\text { Wisata } \\
\text { wan }\end{array}$ & $\begin{array}{l}\text { Jan } \\
\text { s. }\end{array}$ & $F e b$ & $\begin{array}{c}\text { Mar } \\
. .\end{array}$ & April & Mei & Juiit, & Jult & $A g t$ & Sept & Okt & Nov & Des \\
\hline 1. & $\begin{array}{l}\text { Brayut, } \\
\text { Sleman }\end{array}$ & $\begin{array}{l} \\
\text { Wisman } \\
\text { Wisnus }\end{array}$ & 264 & 400 & 328 & 400 & 312 & 450 & 320 & 40 & 320 & 320 & 300 & 250 \\
\hline 2. & $\begin{array}{l}\text { Tanjung, } \\
\text { Nganglik }\end{array}$ & İdem & 567 & 481 & 721 & 815 & 571 & 1.078 & 602 & 113 & 411 & 122 & 1.047 & 1.142 \\
\hline 3. & $\begin{array}{l}\text { Sambi, } \\
\text { Pakem }\end{array}$ & Idem & 0 & 0 & 0 & 0 & 0 & 0 & 0 & 0 & 0 & 0 & 0 & 0 \\
\hline 4. & $\begin{array}{l}\text { Grogol, } \\
\text { Seyegan }\end{array}$ & Idem & 60 & 50 & 70 & 80 & 50 & 50 & 70 & 105 & 230 & 50 & 105 & 1.277 \\
\hline 5. & $\begin{array}{l}\text { Srowolan } \\
\text { Banyu } \\
\text { milir }\end{array}$ & Idem & 0 & 0 & 0 & 0 & 0 & 0 & 0 & 0 & 0 & 0 & 0 & 0 \\
\hline 6. & $\begin{array}{l}\text { Kembang } \\
\text { Arum } \\
\text { Turi }\end{array}$ & Idem & 2.006 & 1.665 & 1.825 & 1.301 & 1.108 & 2.445 & 1.995 & 526 & 1.623 & 3.653 & 2.226 & 2.583 \\
\hline 7. & $\begin{array}{l}\text { Kelor, } \\
\text { Turi }\end{array}$ & Idem & 645 & 561 & 899 & 778 & 861 & 979 & 933 & 799 & 678 & 739 & 891 & 601 \\
\hline 8. & $\begin{array}{l}\text { Penting } \\
\text { sari, } \\
\text { cangkri } \\
\text { ngan }\end{array}$ & Idem & 2.402 & 2.517 & 2.950 & 3.188 & 3.748 & 4.435 & 543 & 423 & 3.300 & 3.485 & 3.588 & 3.999 \\
\hline
\end{tabular}

Data jumlah pengunjung Daya Tarik Wisata di Kabupaten Sleman tahun 2013 sebagai berikut :

Jumlah wisatawan atau data kunjungan wisatawan Kabupaten Sleman tahun 2012-2013 khusus untuk desa wisata dengan obyek wisata yang lain. Rekapitulasi kunjungan wisatawan 2012-2013 sebagai berikut : 


\begin{tabular}{|l|l|l|l|l|l|l|l|}
\hline & & & 2012 & & & 2013 & \\
\hline No & Obyek & Domestik & $\begin{array}{l}\text { Manca } \\
\text { Negara }\end{array}$ & Jumlah & Domestik & $\begin{array}{l}\text { Manca } \\
\text { Negara }\end{array}$ & Jumlah \\
\hline 1. & Candi & 1.238 .410 & 185.821 & 1.424 .231 & 1.409 .337 & 202.652 & 1.611 .989 \\
\hline 2. & Museum & 596.040 & 18.136 & 614.176 & 728.993 & 15.803 & 744.796 \\
\hline 3. & $\begin{array}{l}\text { Obyek } \\
\text { Wisata }\end{array}$ & 839.468 & 29.692 & 869.160 & 836.840 & 24.726 & 861.566 \\
\hline 4. & $\begin{array}{l}\text { Desa } \\
\text { Wisata }\end{array}$ & 104.558 & 29.929 & 134.487 & 145.661 & 3.615 & 149.226 \\
\hline 5. & $\begin{array}{l}\text { Upacara } \\
\text { Adat dan } \\
\text { Event }\end{array}$ & 298.200 & 78.000 & 376.200 & 190.000 & 56.000 & 246.000 \\
\hline & Jumlah & 3.076 .676 & 341.578 & 3.418 .254 & 3.310 .781 & 302.796 & 3.613 .577 \\
\hline
\end{tabular}

\section{Rekapitulasi Kunjungan Wisatawan 2012-2013}

Sumber Data diolah kembali dari Dinas Kebudayaan \& Pariwisata Kab Sleman

Melihat data rekapitulasi data kunjungan wisatawan untuk desa wisata dibanding dengan Obyek Wisata lainnya relatif paling sedikit. Beberapa hal yang di temui di lapangan menyatakan bahwa relatif tingkat kunjungan di desa wisata hanya untuk alternatif tinggal dengan alasan tidak mendapat hotel, biaya lebih relatif terjangkau dan wisatawan domestik lebih mendominasi dibanding wisatawan manca negara. Namun dibanding dengan data dari tingkat kunjungan wisatawan baik domestik/nusantara maupun manca negara untuk desa wisata sendiri mengalami persaingan ketat dan melihat Kembangarum adalah salah satu contoh desa wisata berbasis budaya sehingga perkembangan dari bulan ke bulan di tahun 2013 sangat mengalami kenaikan yang signifikan dibanding dengan desa wisata lainnya, kecuali desa wisata Pentingsari yang memang memiliki karakterisitik lebih beda dari desa wisata Kembangarum, Turi. 
Studi ini juga menghasilkan temuan bahwa, secara umum dengan pengembangan pemberdayaan masyarakat (komunitas setempat) melalui pariwisata sangat membawa dampak positif dan merupakan salah satu model pengembangan pembangunan pariwisata ke depan. Pemberdayaan yang tidak hanya mengembangkan potensi ekonomi masyarakat yang sedang tidak berdaya, namun berupaya juga dapat meningkatkan harkat dan martabat, rasa percaya diri dan harga diri (kebanggaan) serta terpeliharamya tatanan nilai budaya setempat.

Konstruksi yang dibangun dari model desa wisata di Kembangarum, Turi dengan melakukan pemberdayaan masyarakat setempat dari sisi keterkaitan baik ke belakang dan ke depan seperti telah dijelaskan di awal, pada akhirmya juga akan diadopsi sebagai suatu strategi pembangunan sosial ekonomi dan budaya serta lingkungan yang diimplementasikan dalam kerangka design pengembangan pembangunan pariwisata yang berpusat pada rakyat yang kreatif dengan sasaran tidak saja hanya menumbuhkan dan mengembangkan nilai tambah ekonomi tetapi juga nilai tambah yang bersifat beyond economic and environmental (sosial budaya dan lingkungan).

Temuan yang menarik untuk di cermati dalam penelitian ini adalah pemahaman power empowerment ternyata dapat menempatkan konsep pemberdayaan masyarakat sebagai bagian dari upaya membangun eksistensi pribadi, keluaga, masyarakat, bangsa, pemerintah, negara dan dunia sekalipun dalam kerangka proses aktualisasi kemanusiaan yang adi dan beradab yang terwujud dalam kehidupan Desa Wisata Kembangarum, Turi ini. Falsafah Jawa "Guyub" yang artinya saling gotong royong cerminan masyarakat dalam tatanan budaya yang sangat harus diperhatikan dan dilestarikan sebagai bentuk kearifan lokal dan wajib bisa 
"terjual" dengan baik ke wisatawan manca negara yang mungkin tidak memiliki tatanan budaya yang sama.

\section{Kesimpulan dan Saran}

Dari hasil penelitian dan pembahasan di peroleh kesimpulan sebagai berikut :

1. Peran pemerintah sebagai fasilitastor dan regulator, Swasta sebagai industri/pengembang investor juga masyarakat sebagai tuan rumah, pelaksana atau subyek pengembangan sebagai pemangku kepentingan dalam pariwisata.

2. Pengembangan ekonomi kreatif harus dapat menghasilkan outcome dari hulu ke hilir sebagai wujud dengan konstalasi tata kelola kepariwisataan yang baik dimana posisi masyarakat dalam berbagai kesempatan masih berada dalam posisi yang tidak seimbang dibanding stakeholder (pemerintah dan industri), sehingga perlu pengupayaan dalam peningkatan power masyarakat yang cenderung mengalami powerless dalam konteks kepariwisataan yang berbasis good tourism governance sehingga perlu semakin ditingkatkan peran peningkatan kearifan lokal yang berbasis budaya dalam hal ini peran Desa Wisata perlu diangkat baik dalam promosi, pemasaran juga standar pelayanan yang bersifat tidak hanya untuk wisatawan nusantara namun berskala internasional.

3. Peningkatan pembangunan ekonomi kreatif dalam hal ini untuk mendapatkan keungggulan bersaing sebagai "ceruk pasar" (niche market) potensial maka lingkup pemberdayaan masyarakat sebagai jawaban proses keterkaitan (linkage) baik forward linkage 
maupun backward linkage yang telah dijelaskan didepan akan berhasil sesuai yang diharapkan jika senantiasa menghargai variäsi dan keunikan lokal sebagai pusaka yang patut menjadi value added setiap Desa Wisata khususnya di wilayah Kabupaten Sleman,sehingga kepariwisataan yang dikembangkan harus bersifat fleksibel menyesuaikan dengan kondisi lokal

4. Penekanan proses pembelajaran masyarakat (social learning) yang di dalamnya terdapat interaksi kolaboratif antara birokrasi dan komunitas sejak mulai perencanaan, implementasi sampai dengan evaluasi kegiatan yang ada dengan membentuk kemitraan atau jejaring bermanfaat (network) yang saling menguntungkan diantara stakholder terkait dalam hal ini Desa Wisata dengan industri lain terkait , masyarakat dan pemerintah untuk mencapai keungggulan bersaingnya.

\section{Daftar Pustaka}

Sunarya, Bambang . 2013. "Kebijakan pembangunan Destinasi Pariwisata" konsep dan aplikasinya di Indonesia

Statistik Kebudayaan dan Pariwisata Kabupaten Sleman tahun 2013 Dinas Kebudayaan dan Pariwisata Kabupaten Sleman

Pitana, Gayatri 2005 “ Sosiologi Pariwisata” kajian Sosiologis terhadap struktur, sitem dan dampak dampak pariwisata.

Desa Wisata Kembangarum Turi , Pemandu Wisata Bahan Leaflet dan Katalog

Sangadji, Sopiah 2013 “ Perilaku Konsumen: pendekatan praktis “ Himpunan Jurnal Pariwisata 